\title{
Multicultural and Global Citizenship in the Transnational Age: The Case of South Korea ${ }^{1}$
}

\author{
Seungho Moon \\ Teachers College, Columbia University \\ U. S. A.
}

Transnational flows and influx influence perspectives about the concepts of citizenship limited within nation-state borders. The author challenges liberal assimilationist conceptions of citizenship education in order to explore possibilities for the advancement of both multicultural citizenship and global citizenship education. He situates South Korea's case within this discourse and suggests multicultural citizenship and global citizenship education as

alternative, defensible, and appropriate paradigms at the transnational and global age. In the final part of the paper, he discusses the implications of this paradigm for citizenship education in South Korea.

A Transnational Age and Global Citizenship Education Transnational Flows in Korea

Tensions in Citizenship Education: Liberal Assimilationists vs. Multiculturalists Multicultural Citizenship in the Transnational Context Conclusion Endnotes References

The concepts of citizenship and citizenship education vary among researchers. Figueroa (2004) defined citizenship as a range of qualities, values, and virtues that citizens should have and cultivate, including "equality, autonomy, solidarity, and judgment" (p. 226). Focusing on Asian contexts, Lee (2004) argues for citizenship grounded in three major Asian values: spirituality, harmony, and individuality. As citizenship education usually deals with students' values and attitudes of equality, liberty, rights, responsibilities, autonomy, diversity, and harmony in a democratic society, this notion of citizenship education denotes citizens within a nation-state and focuses on local issues.

Since the world has changed from a space of "places" to a space of "flows," people residing in the transnational world need to develop new notions of citizenship. The very foundations of nation-state, such as a homogenous culture and society, are being challenged by a transnational population of immigrants 
(Castles, 2004). The notions of citizenship education go beyond the limited nation-state border to the global community (Kymlicka, 2004).

South Korea is not an exception to transnational flows in an economic, political, and cultural sense. A long-standing belief that Korea is an ethnically, linguistically, and culturally "homogeneous" society has been challenged by recent migrant workers, families, and ethnically diverse student populations from different countries. In this context, the following questions arise: how might such transnational movements encourage Korean educators to reframe citizenship education? What kind of discourse about citizenship education meets the needs of diverse global communities? In what ways can Korean educators and policy makers possibly address these transnational issues in citizenship education?

The purpose of this paper is to examine current discourses about citizenship that can advance Korea's citizenship education. It explores the notions of citizenship education in the era of transnational mobility. South Korea provides an example of how transnational migration is shifting a nation's longstanding belief of an ethnically "homogenous" society to a diverse one within a decade. After examining issues and tensions regarding citizenship education, I explore what characteristics of citizenship education might fit in a Korean context. At the end, this paper highlights the implications of this new paradigm for policy and practices in Korea.

\section{A Transnational Age and Global Citizenship Education}

A goal of citizenship education in most nation-states is to "help students develop allegiance" to their nation-states (Banks, 2009b, p. 105). This agenda assumes that an individual's citizenship is limited to one nation-state. However, current transnational migration waves and the existence of culturally diverse populations challenge the notions of citizenship that is limited to one nation-state (Koopmans \& Statham, 1999). These developments raise complex and difficult questions about citizenship education (Dominique, 2001; Ghai, 2000; Parekh, 2000; Patten, 2001). For example, Soysal (1998) emphasized a new form of citizenship that transcends the boundaries of the nation-state when she stated:

Rights that used to belong solely to nationals are now extended to foreign populations, thereby undermining the very basis of national citizenship. This transformation requires a new understanding of citizenship and its foundation (p. 190).

Transnational ebbs and flows challenge nation-state borders and mobilize the notion of citizenship into global community. Within this global context, educating students to function in one nation-state does not prepare them for global citizenship. It is inconsistent with the racial, ethnic, and cultural realities of their society (Luchtenberg, 2004; Murphy-Shigematsu, 2004). As Koopmans and Statham (1999) postulated, the outside forces of globalization interrupt the nation-state's position as the predominant unit of social organization. The 
increasing pluralization and capitalization of transnational communities weaken the nation-state's legitimacy, authority, and integrative capacities. In this sociopolitical, economic, and cultural context, the imagined global and multicultural communities become extremely diverse in their cultural and social characteristics (Kymlicka, 2004).

The major goals of citizenship education should be expanded to develop students' understandings of the "interdependence" among nation-states in the transnational and transcultural community. The expanded version of citizenship education should help students clarify their attitudes toward other nations and people. It should also encourage students to develop global and cosmopolitan identifications (Banks, 2004). Once such identification is developed, the question of how these multicultural, transnational, and cosmopolitan waves change the notions of citizenship education in the nation-state level must be answered. What happens to a nation-state in which the transnational mobilities and influx have strongly influenced a society? In the following sections, I explore the case of Korea to examine the impact of transnational flows and mobility on citizenship and citizenship identity. This examination provides insights for interrogating the notion of citizenship education that is appropriate in this global age.

\section{Transnational Flows in Korea}

Global migration challenges nation-states and schools about how to educate people who have ethnic backgrounds different from the mainstream ethnic groups. South Korea is not an exception to this world-wide phenomenon because its demographics have dramatically changed since the 1990s. In 2008, approximately one million foreign nationals lived in Korea, which was more than $2 \%$ of the total population. The rate of foreign nationals increased more than $17 \%$ from 2008 to 2009 (Moon, 2010). In this section, I examine demographic changes in Korea and introduce how textbooks attempt to address Korean society from mono-ethnic society to multi-ethnic society.

\section{Demographic Changes}

A decade ago, most mainstream Korean citizens did not challenge the myth that Korea consists of "one-blood, one-language, and one-culture." This belief had been used to teach Korean nationalism in public schools (Tschong, 2009; Won, 2008). The transnational migrants, however, began dismantling this "one-blood and one-nation" myth in Korea primarily because of the increasing number of 1) migrant workers, 2) international marriages between Korean citizens and migrants, and 3) North Korean defectors (Kim, Lee, Kim, \& Cha, 2009). Beginning in the 1990s, foreign workers were permitted to work in Korea. In 2007 more than 630,000 foreign workers resided in Korea (S. A. Kim, Lee, Kim, \& Cha, 2009). Initially, the Korean government designed the "Internship 
Training Program for Foreign Workers" in 1993. These workers, mainly from China and South East Asia, were assigned to predominantly "3D" (Dirty, Dangerous, and Difficult) jobs that domestic workers refused to accept (Tschong, 2009). This program had been developed as an "Internship-Recruitment" system in 2000, and these foreign workers could get full time jobs in Korea after the internship. In 2004, the Korean government changed this internship-based program to the "Employment Approval System" after establishing the "Employment of Foreign Worker Law in 2003." The law was enacted because the discrimination against foreign workers and human rights violations were significant social issues (e.g., below minimum wage payment and physical abuse).

In 2001, $77.4 \%$ of foreign workers were undocumented [illegal immigrants]. Ever since the "Employment Approval System" was enacted in 2004 , the percentage of undocumented foreign workers has been approximately $50 \%$. This number is relatively high compared with that of Japan $(32 \%)$, Singapore $(3 \%)$, and Taiwan $(7 \%)$. The number of unregistered school-age children cannot be estimated because the parents are afraid of sending their children to school because of their undocumented immigrant status (Won, 2008).

International marriages between Korean citizens and migrants dramatically increased in the 2000s. In 2007, international marriages comprised $11.1 \%(38,291)$ of all marriages. More than $75 \%$ of international marriages were between a Korean husband and a migrant wife. This rate was higher in rural areas $(35.9 \%)$ than the national average $(11.1 \%)$ because many Korean males in their 30s and 40s in rural areas could not find Korean spouses (Kang, 2008; Nahm \& Jang, 2009). In 2006, the major countries of origin of foreign wives who married Korean husbands include China (66.2\%), Vietnam (18.7\%), Japan (4\%), the Philippines (3.2\%), and Mongolia (1.8\%) (Won, 2008). Most immigrant wives were Korean-Chinese (e.g., from the Yeon Byun area) who share Korean language and similar culture. In 2008, almost 18,800 students in public schools were from these multicultural families ${ }^{2}$. This is $39.6 \%$ more than the previous year.

The number of North Korean defectors residing in South Korea has also increased sharply since the mid-1990s. In 2007, more than 10,000 North Korean defectors (Sae-to-min in Korean) lived in South Korea (Won, 2008). Although North Koreans and South Koreans share the same ethnic backgrounds and Korean language, albeit different dilects, North Korean defectors are experiencing serious cultural and political problems in South Korea. In the Korean multicultural discourse, major attention has focused on people from diverse ethnic and racial background that are not Korean. However, North Korean defectors are part of the "marginalized" group in that their different political and cultural upbringing is different from mainstream Koreans (S. A. Kim, et al., 2009). 


\section{Changes in the Textbooks from Mono-ethnic to Multi-ethnic Society}

Mainstream Korean citizens used to believe that Korea consists of "oneblood, one-language, and one-culture." The Convention on the Elimination of Racial Discrimination (CERD) in the United Nations (UN) has pointed out that the "pure-blooded" ideology and the notions of ethnic homogeneity have resulted in various forms of discrimination in Korea (Wagner, 2009). CERD has recommended recognizing the multi-ethnic character of contemporary Korean society and promoting understanding, tolerance, and friendship among the different ethnic and national groups in Korea. In education, CERD has recommended that the Korean government include human rights awareness programs in the official curriculum. A revised curriculum should describe a Korean society in which people from multiple ethnic and cultural backgrounds live together harmoniously (Hong, 2008; Wagner, 2009).

Mono-ethnicism was not officially removed from K-12 social studies and moral education textbooks until February, 2007. For example, social studies textbooks for sixth graders used to mention that "Korea consists of one ethnic group. We, Koreans, look similar and use the same language" (Mo, 2009). Citizenship education was grounded in this mono-ethnicism, and the national curriculum focused on enhancing democratic citizenship, including obedience to the law, rights as citizens, morality, and loyalty to the nation (Yang, 2007). Global citizenship emphasized how to increase global competency in the global market and become a world citizen. Global education aimed at helping students acquire the knowledge, skills, and attitude to understand different cultures in the supposedly "developed" countries for Korea's economic, cultural, and political advancement (e.g., table manners, English, and appropriate non-verbal language).

The Korean government has acknowledged dramatic social changes in contemporary Korean society and has attempted to implement this view of contemporary Korean society in national curriculum standards. National curriculum standards have replaced mono-ethnicism with the notions of cultural diversity and multiculturalism. Despite recent effort to revise the national curriculum, there still exist barriers to the ethnically mainstream Koreans for how to deal with the issues of diversity and citizenship with migrant population groups (Kim, et al., 2009; Mo, 2009).

\section{Tensions in Citizenship Education:}

\section{Liberal Assimilationists vs. Multiculturalists}

Since the 2000s, Korean educators and policy makers have been struggling with how to respond to the issues of diversity and citizenship education 
influenced by transnational flows and global change. Apparently, tensions exist in policy making between liberal assimilationist notions of citizenship and multicultural citizenship ${ }^{3}$. The liberal assimilationist concepts of citizenship posit that every citizen must surrender his/her cultural attachments for equity, integrity, and social cohesion. They emphasize cultural assimilation into the dominant culture of a nation-state. According to Banks (2008), the liberal assimilationist assumes that strong attachment to cultural identity groups causes social conflicts and leads to harmful division. In contrast, multicultural citizenship recognizes the "unequal power relation that exists between and among various ethnic, racial, and cultural groups" (Ladson-Billings, 2004, p. 113). Advocates of multicultural citizenship discuss the problems that result from the fact that students from diverse cultural and ethnic groups do not sufficiently experience civic equality and recognition in state or public schools (Gutmann, 2004).

\section{Liberal Assimilationist Notions of Citizenship in Korea}

Liberal assimilationist notions of citizenship in Korea originated from three major values: 1) equal opportunity, 2) political, economic, and social advancement, and 3) social unity and harmony. First, liberal assimilationists are concerned that educational discrimination and other forms of exclusion occur when people emphasize their attachment to specific cultural groups. They believe that equal opportunity means to provide the mainstream cultural resources to these "newcomers" or cultural "Others" because not teaching the mainstream cultures would hinder new immigrants' full participation in society. Liberal assimilationist notions of citizenship focus on this "deficient-oriented" model. "Adding" the cultural and linguistic characteristics of the mainstream culture becomes the major goal of citizenship education. For example, the Ministry of Education, Science, and Technology is supporting Korean as Second Language (KSL) programs both for non-Korean mothers and their children (e.g., Kosian). The KSL program is grounded in the assimilation of ethnic minorities. This approach does not actively support bilingual education for the children from multicultural families (Tschong, 2009). Rather, it purports to increase Korean literacy when children from multicultural families go to public schools.

The liberal assimilationists posit that the "one-culture and one-nation" model benefits Korea's political, economic, and social advancement. Traditionally, the "one blood, one culture, and one nation" ideology has been utilized to protect Korea from countless invasions from the regime of China, Japanese colonization (1910-1945), endless ideological conflicts with North Korea (since 1948), and political, cultural, and economical influx from the Western countries (Yang, 2007). This "one-blood and one-culture" nationalism has been used politically, culturally, and economically for social solidarity and unity. Although the ideal or the myth of an ethnically homogenous country has been deconstructed because of the huge transnational influx, the liberal 
assimilationists believe that socio-political, cultural, and economic advancement of Korea is possible only if there is a unified national ideal, goal, and culture.

Liberal assimilationists use Confucianism to support their arguments about social harmony and unity. According to Wang (2004), the conservative perspective of Confucianism pursues "social harmony" more from the commonality of humanity [or groups] than from individual differences. Consequently, it tends to suppress individuality and differences to promote social harmony. Guided by this cultural and ideological foundation, "something different" from the majority group is regarded as "something wrong." A set of social norms generates normalizing judgment about individuals who are different from the "mainstream" culture.

Differences are considered "abnormal" factors that inhibit social "unity" (Yoon, 2008). Not speaking Korean is wrong because it hinders social unity. Ethnically "half" Koreans" or "non-Korean" students who do not follow "Korean culture" are considered socio-culturally deficient (e.g., using formal language to the elders and authority, showing respect appropriately to teachers). This attitude has nurtured unfriendliness toward heterogeneity and prejudice against students whose backgrounds are different from the mainstream culture. Liberal assimilationists posit that the marginalized groups' assimilation into the mainstream culture is imperative in order to minimize prejudice and discrimination and to increase social unity. At the same time, each individual's sacrifices and struggles to get assimilated into the "Korean" culture is believed to be appropriate for social unity as long as "they [the ethnic minority group]" want to live in "our [Korean]" society. Overall, the advocates of liberal assimilationist notions of citizenship emphasize a "one national identity" ideology that has been sustaining the unified version of "Korean-ness." Keeping the Korean national identity and educating "Other" people about the "Korean-ness" become the main goals of citizenship education.

\section{Multicultural Citizenship in Korea}

Multicultural citizenship advocates challenge the liberal assimilationist notions of citizenship because this approach ignores the importance of fulfilling the need for students to maintain their commitments to local communities, cultures, and their homelands (Banks, 2008). They support the multiculturalist approach for four major reasons: 1) social unity from accepting differences, 2) existence of multiple cultural citizenship, 3) multiplicity of Korean identities, and 4) connection with global citizenship.

Korean multiculturalists argue that social unity and harmony result from accepting differences among diverse cultural groups and believe that citizenship education should embrace the deepening diversity within Korean society. Multiculturalists postulate that "unity without diversity results in cultural hegemony" (Banks, 2009b). Cultural repression results when the "mainstream" 
group forces "marginalized" groups to give up their own racial, cultural, ethnic, linguistic, and religious heritage in order to create unity.

Multicultural citizenship strongly challenges the assumption that only "one" citizenship exists for "one" nation-state. It differentiates the notions of "cultural citizenship" and "nation-state citizenship." For example, in the US context, people of color are "constructing a new type of citizenship" (Ladson-Billings, 2004, p. 117). They categorize their identity using racial/ethnic group (e.g., African American or Asian American) because Whiteness is synonymous with Americanness in the US (Banks, 2008; Ladson-Billings, 2004). Similar to US context, Korean multicultural citizenship advocates argue that multiple layers of cultural citizenship exist in Korea. This multiplicity cannot be explained using a monolithic version of "Korean" citizenship. This approach aims to help citizens from the marginalized cultural groups attain civic equality and recognition in multicultural democratic society.

Multicultural citizenship scholars posit that identities (e.g., Korean identities) are complex, contextual, and malleable among citizens within the same nation-state (Murphy-Shigematsu, 2004; Oh, 2008). As Anderson (1983/2006) pointed out, a nation-state is an "imagined community," where the illusion of nationalism and collectivity exist among the citizens within a nationstate. According to the notion of multicultural citizenship, it is imperative to move from monolithic and static definitions of a nation-states identity toward the recognition of multiple identities. The myth and practice of a "monoethnic" and "monocultural" nation-state excludes marginalized cultural groups from Korean society. Schools and Korean society cannot expect students from different ethnic backgrounds to feel structurally included within Korea and to develop a strong loyalty to it while marginalizing their cultural assets (Banks, 2009a). Multicultural citizenship educators challenge the liberal assimilationist notions of citizenship that attempt to abolish the "funds of knowledge" that students from marginalized groups bring into schools (Gonzalez, Moll, \& Amanti, 2005).

Multicultural citizenship and global citizenship are interrelated, not discrete. Multicultural citizenship is closely connected with global citizenship in that multicultural education can intersect with global citizenship in the midst of transnational flows and mobilities (Banks, 2008). Educators need to consider multicultural citizenship and global citizenship simultaneously when they work with students. Educators should work with students on the basic principles of power inequity, toleration, and recognition for civic equalities and cosmopolitan ideals. Multicultural citizenship is a vehicle for expanding the notions of citizenship education beyond the limited nation-state boundaries to transnational communities. Multicultural citizenship can be connected with practicing not only tolerance of different identities but also openness to differences within individuals, nation-states, and global communities. 


\section{Multicultural Citizenship in the Transnational Context}

I support multicultural citizenship rather than the liberal assimilationist notion of citizenship. Multicultural citizenship foregrounds sociological and political understandings of an identity which is multiple, complex, complicated, and negotiated. This approach provides a critical analysis of the structural inequalities and injustice that impact students and families from the marginalized groups. Multicultural citizenship allows all participants to recognize and examine the complex interconnections, chasms, and dissonances that occur between their own and other ethnic and cultural identities as well as other forms of social identity (May, 2009).

Advocates of multicultural citizenship in Korea acknowledge the struggles of the socially marginalized groups, which have resulted from the persistent belief of one-nation, one-blood, and one-culture. Furthermore, the multicultural citizenship approach aims to embrace diversity and multiculturalism and encompasses teaching Korean language and culture to the marginalized groups in Korea. Although accepting the reality that the Korean language is a survival tool for living in Korea, multicultural advocates challenge the liberalist assimilationist notions of citizenship that destroy each cultural group's assets, including their own language, culture, and social behavior under the monolithic goal of social unity and cohesiveness.

Persuaded by multicultural citizenship education theorists (Banks, 2008; Gutmann, 2004; Kymlicka, 2004), I challenge cultural norms that liberal assimilationists set up for a monolithic version of social unity. These social norms easily judge people using binary concepts, including Korean/non-Korean, domestic/foreign, full Korean/half Korean, appropriate/inappropriate, good/bad, or harmony/discord. Similar to the Black/White dichotomy in the US context, Korea's case shows how we/they distinctions are drawn to "normalize and standardize the culture and provide the postulates against which people measure themselves" (Ladson-Billings, 2004, p. 100). Grounded in multicultural citizenship, I challenge why the norms, such as Korean-ness and integrity, should constrain and govern life in terms of who "will and will not be a livable human being" in a society (Butler, 2004, p. 206).

\section{Conclusion}

This paper has emphasized the importance of multicultural citizenship education rather than liberal assimilationist citizenship for civic equality and the marginalized groups' request for cultural recognition and rights (Banks, 2009b). Guided by this positionality, I propose some educational and policy implications for Korea's citizenship education. 
Korean educators and policy makers need to realize that unity and diversity can go together when we tolerate differences and recognize diversity. Unity without diversity causes cultural repression of "marginalized" groups (Banks, 2008). There is a fear in the society that social unity will disappear once a nation-state accepts different cultures. I argue that the consequences are opposite. As the French riots in November 2005 demonstrate (Lemaire, 2009), once a nation-state does not recognize diversity in a country and continues an extreme assimilation or integration policy, the dream for social unity begins shrinking.

As part of recognizing diversity, it is imperative to educate students from the "mainstream" culture about multicultural citizenship. Education for antidiscrimination and cultural awareness is an important goal for multicultural citizenship. Recognizing differences and celebrating them are also important goals. Multicultural citizenship education should not be limited to teaching about understanding differences. Students should also have opportunities to think critically about what socio-cultural, economic, and international politics generate multicultural society. A delicate balance between diversity and unity is possible only if students can consider these questions in schools.

"Political literacy" is a prerequisite for educating students about multicultural and global citizenship. Political literacy is not simply teaching students historical facts or socio-political data. Politically literate citizens internalize values of differences, tolerance, and acceptance. They do not impose their values on other people. Rather, they negotiate, persuade, and reason with evidence. Teaching political literacy enables students to become citizens who are critical decision makers and social activists for more equitable and just cultural, local, and global communities.

I suggest collaboration between schools and grassroots organizations as one way to teach political literacy. Korean civil activists have been actively working and supporting the marginalized groups to help them attain equal human rights of multicultural families and students, North Korean defectors, and undocumented workers (Yoon, 2008). For example, The Borderless Village is a project designed and run by NGO, and it demonstrates grassroot multiculturalism in Korea. This project aims to advance migrated workers' human rights and abolish social discrimination against them in Korean society (Oh \& Jung, 2006). Their active roles as multicultural citizens have mobilized governments to implement policies to assist and empower non-Korean and marginalized populations. The collaboration between schools and grassroot organizations provides valuable teaching-learning opportunities that enable students to experience the meanings of multicultural and global citizenship in their local communities.

Korean educators and policy makers should think about how to educate citizens that meet the needs of a transnational and cosmopolitan society. Concurring with Gonçalves e Silva (2004), I believe that a citizen is a person who works against social injustice both for individual recognition and for the benefit of "all" people. Korean educators should ensure that the goal of multicultural and 
global citizenship education is consistent with the founding ideology of Korea in $2333 \mathrm{BC}$ (Hongikinkan, 홍익인간 in Korean). Framed by this ideology, The Fundamentals of Korean Education Act indicates that the purpose of Korean education is to cultivate Korean citizens to contribute to democracy and mutual prosperity of all human beings (Park, 2008). Korea has a strong philosophical asset, Hongikinkan, which encourages students to work with "all" human beings for mutual prosperity and equal human rights. This asset should be expanded not by the liberal assimilationist conceptions of citizenship but by those of multicultural and global citizenship.

\section{Endnotes}

1. I thank Professor James A. Banks for encouraging and helping me develop this paper from a doctoral seminar at Teachers College, Columbia University in summer 2009.

2. "Children from multicultural families" refers to children whose parent(s) have different ethnic background(s) from Korean. This expression substitutes for other derogatory terms, such as "mixed-blood children," "mixed racial children," or "foreign children" (S. I. Kim, 2009). A compound word "Kosian" (Korean+Asian) is one of the ways to refer to children from multicultural families that include one parent from another Asian country.

3. The conflict between liberal assimilationist notions of citizenship and multicultural citizenship is a longstanding debate of multiculturalism in the US and other countries. I acknowledge that multiple voices and politics exist within the multicultural citizenship approach. For example, Wieviorka (1998) challenges multiculturalism because it does not deeply delve into diverse notions of difference and the subjectivity of individuals. Similarly, Tiryakian (2004) categorizes multiculturalism as 1) cultural nationalism, 2) state policy, and 3) social philosophy. He theorizes different aspects of multiculturalism depending on its theoretical and socio-political foundations.

Despite these multiple dimensions of multicultural citizenship, this paper defines multicultural citizenship that values cultural pluralism and advocates differences among cultural groups. Since Korea has only begun confronting multiculturalism and diversity quite recently, it is valuable to address this debate between liberal assimilationist notions of citizenship and multicultural citizenship. This juxtaposition leads to subsequent arguments to expand the notion of citizenship to multicultural global citizenship in the transnational context.

\section{References}

Anderson, B. (1983/2006). Imagined communities (2 ${ }^{\text {nd }}$ ed.). New York: Verso. 
Banks, J. A. (2004). Introduction: Democratic citizenship education in multicultural societies. In J. A. Banks (Ed.), Diversity and citizenship education: Global perspectives (pp. 3-16). San Francisco: Jossey-Bass.

Banks, J. A. (2008). Diversity, group identity, and citizenship education in global age. Educational Researcher, 37(3), 129-139.

Banks, J. A. (2009a). Diversity and citizenship education in multicultural nations. Multicultural Education Review, 1(1), 1-28.

Banks, J. A. (2009b). Human rights, diversity, and citizenship education. The Educational Forum, 73(2), 100-110.

Butler, J. (2004). Undoing gender. New York: Routledge.

Castles, S. (2004). Migration, citizenship, and education. In J. A. Banks (Ed.), Diversity and citizenship education: Global perspectives (pp. 17-48). San Francisco: Jossey-Bass.

Dominique, A. (2001). Political stability in multinational democracies. In A. G. Gagnon \& J. Tully (Eds.), Multinational democracies (pp. 65-96). New York: Cambridge University Press.

Figueroa, P. (2004). Diversity and citizenship education in England. In J. A. Banks (Ed.), Diversity and citizenship education: Global perspectives (pp. 219-244). San Francisco: Jossey-Bass.

Ghai, Y. (Ed.). (2000). Autonomy and ethnicity: Negotiating competing claims in multi-ethnic states. New York: Cambridge University Press.

Conçalves e Silva, P. B. (2004). Citizenship and education in Brazil: The contribution of Indian peoples and Blacks in the struggle for citizenship and recognition. In J. A. Banks (Ed.), Diversity and citizenship education: Global perspectives (pp. 185-214). San Francisco: Jossey-Bass.

Gonzalez, N., Moll, L. C., \& Amanti, C. (2005). Funds of knowledge: Theorizing practices in households, communities, and classrooms Mahwah, $\mathrm{NJ}$ : Lawrence Erlbaum Associates.

Gutmann, A. (2004). Unity and diversity in democratic multicultural education. In J. A. Banks (Ed.), Diversity and citizenship education: Global perspectives (pp. 71-96). San Francisco: Jossey-Bass.

Hong, W. (2008). 한국적 다문화 교육의 발전 방안 탐색: 미국 논의의 수용을 넘어서 [Inquiry on the advancement of Korean multiculturalism: Beyond the US discourses]. 교육원리연구 [Educational Principle Inquiry], 13(2), 89-113.

Kang, H. (2008). 한국 다문화사회의 형성 요인과 통합 정책 [Integration of Korean multicultural society: Factors and policy directions]. 국가정책연구[National Policy Research], 20(2), 5-34. 
Kim, S. A., Lee, S. H., Kim, M. Y., \& Cha, Y. (2009). Redesigning Korean teacher education in multicultural social context. Paper presented at the KAME 2009 International Conference, Hanyang University, Seoul, Korea.

Kim, S. I. (2009). The prospect and problem of multicultural education in globalization. Paper presented at the KAME 2009 International Conference, Hanyang University, Seoul, Korea.

Koopmans, R., \& Statham, P. (1999). Challenging the liberal nation-state? Postnationalism, multiculturalism, and the collective claims making of migrants and ethnic minorities in Britain and Germany. American Journal of Sociology, 105(3), 652-696.

Kymlicka, W. (2004). Foreword. In J. A. Banks (Ed.), Diversity and citizenship education: Global perspectives (pp. xiii-xviii). San Francisco: Jossey-Bass.

Ladson-Billings, G. (2004). Culture versus citizenship: The challenges of racialized citizenship in the United States. In J. A. Banks (Ed.), Diversity and citizenship education: Global perspectives (pp. 99-126). San Francisco: Jossey-Bass.

Lee, W. O. (2004). Concepts and issues of Asian citizenship: Spirituality, harmony and individuality. In W. O. Lee, D. L. Grossman, K. J. Kennedy \& G. P. Fairbrother (Eds.), Citizenship education in Asia and the Pacific concepts and issues (pp. 277-288). Hong Kong: Comparative Education Research Centre, The University of Hong Kong.

Lemaire, E. (2009). Education, integration, and citizenship in France. In J. A. Banks (Ed.), The Routledge international companion to multicultural education (pp. 323-333). New York: Routledge.

Luchtenberg, S. (2004). Ethnic diversity and citizenship education in Germany. In J. A. Banks (Ed.), Diversity and citizenship education: Global perspectives (pp. 245-272). San Francisco: Jossey-Bass.

May, S. (2009). Critical multiculturalism and education. In J. A. Banks (Ed.), The Routledge international companion to multicultural education (pp. 33-48). New York: Routledge

Mo, K. (2009). Multicultural education in Korean social studies. Paper presented at the KAME 2009 International Conference, Hanyang University, Seoul, S. Korea.

Moon, H. (2010). 통계로 본 2008 한국 [Census 2008 in Korea]. 한국일보 [Hankook Ilbo]. Retrieved February 14, 2010, from http://news.hankooki.com/lpage/society/200902/h2009022103174521950. $\underline{\mathrm{htm}}$

Murphy-Shigematsu, S. (2004). Expanding the borders of the nation: Ethnic diversity and citizenship education in Japan. In J. A. Banks (Ed.), Diversity and citizenship education: Global perspectives (pp. 303-332). San Francisco: Jossey-Bass. 
Nahm, I., \& Jang, H. (2009). 결혼이민여성 가족의 출신국 문화이해 [Cultural understanding of the native countries of marriage immigrant women's families]. 사회 이론 [Social Theory] (Spring/summer), 7-29.

Oh, C. (2008). 유아다문화 교육의 현실과 교육적 대안 [The reality of early childhood multicultural education and educational alternatives]. 유아교육학논집 [Korean Journal of Early Childhood Education], 12(4), 167-197.

Oh, K., \& Jung, K. (2006). 안산시 원곡동 "국경없는마을" 프로젝트: 몇 가지 쟁점들 [The borderless village project in Ansan: Issues]. 한국지역지리학회지 [Korean Journal of Regional Geographers], 1(72-93).

Parekh, B. (2000). Rethinking multiculturalism: cultural diversity and political theory. Cambridge, MA: Harvard University Press.

Park, S. (2008). 다문화 사회에서의 학교 교육과정 정책 [School curriculum policy in multicultural society]. 초등교육연구 [The Journal of Elementary Education], 21(2), 1-19.

Patten, A. (2001). Liberal citizenship in multinational societies. In A. G. Gagnon \& J. Tully (Eds.), Multinational democracies (pp. 110-132). New York: Cambridge University Press.

Soysal, Y. N. (1998). Toward a postnational model of membership. In G. Shafir (Ed.), The citizenship debate: A reader (pp. 189-217). Minneapolis, MN: University of Minnesota Press.

Tiryakian, E. A. (2004). Assessing multiculturalism theoretically: E pluribus unum, sic et non. In J. Rex \& G. Singh (Eds.), Governance in multicultural societies (pp. 1-18). Burlington, VT: Ashgate.

Tschong, Y. (2009). 한국사회의 다문화화에 대한 교육학적 성찰 [Educational reflection on the multiculturalization of the Korean society]. 교육철학 [Educational Philosophy], 44, 113-137.

Wagner, B. K. (2009). Scrutinizing rules for foreigners in Korea: How much discrimination is reasonable? Kyung Hee University Law Review, 44(3), 391-416.

Wang, H. (2004). The call from the stranger on a journey home. New York: Peter Lang Publishing.

Wieviorka, M. (1998). Is multiculturalism the solution? Ethnic \& Racial Studies, 21(5), 881-910.

Won, S. (2008). 다문화시대 소수자 정책의 차별적 포섭과 배제: 외국인 대상 정책을 중심으로 한 탐색적 접근[Differentiated inclusion and exclusion of policy for marginalized groups in multicultural age]. 한국행정학보 [Korean Journal of Administration], 42(3), 29-49. 
Yang, Y. (2007). 분단-다문화시대 교육 이념으로서의 민족주의와 다문화주의의 양립가능성 모색 [Compatible between nationalism and multiculturalism as a multicultural education idea in nationally divided multicultural Korean society]. 교육과정연구 [Korean Journal of Curriculum Studies], 25(3), 2348.

Yoon, I. (2008). 한국적 다문화주의의 전개와 특성: 국가와 시민사회의 관계를 중심으로 [The development and characteristics of multiculturalism in South Korea: With a focus on the relationship of the state and civil society], 한국사회학 [Korean Sociology], 42(2), 72-103. 